Article

\title{
Optimization of Cellulase and Xylanase Production by Micrococcus Species under Submerged Fermentation
}

\author{
Ziyanda Mmango-Kaseke ${ }^{1,2}$, Kunle Okaiyeto ${ }^{1,2}$, Uchechukwu U. Nwodo ${ }^{1,2, *}$, \\ Leonard V. Mabinya ${ }^{1,2}$ and Anthony I. Okoh ${ }^{1,2}$ \\ 1 SAMRC Microbial Water Quality Monitoring Centre, University of Fort Hare, Alice 5700, South Africa; \\ zmkaseke@gmail.com (Z.M.-K.); okaiyetofranciskunle@yahoo.ca (K.O.); lmabinya@ufh.ac.za (L.V.M.); \\ aokoh@ufh.ac.za (A.I.O.) \\ 2 Applied and Environmental Microbiology Research Group (AEMREG), Department of Biochemistry and \\ Microbiology, University of Fort Hare, Alice 5700, South Africa \\ * Correspondence: UNwodo@ufh.ac.za; Tel.: +27-786-273-279; Fax: +27-866-286-824
}

Academic Editor: Dimitrios Komilis

Received: 24 August 2016; Accepted: 9 November 2016; Published: 11 November 2016

\begin{abstract}
This paper reports on the optimization of culture conditions for cellulase and xylanase production by bacterial isolate from lignocellulosic biomass. The bacterial isolate was screened for cellulase and xylanase production on carboxyl methyl cellulose (CMC) and birch wood xylan as substrates, respectively. One bacterial isolate showing the highest halo zone diameter (isolate PLY1) was selected for detailed studies. The analysis of the $16 \mathrm{~S}$ ribosomal ribonucleic acid (rRNA) gene nucleotide sequence of PLY1 revealed it to have $98 \%$ similarity to Micrococcus luteus strain Fse9 and the sequence was deposited in the GenBank as Micrococcus luteus strain SAMRC-UFH3 with accession number KU171371. Cellulase production was achieved in the presence of CMC $(1 \% w / v)$ under an incubation temperature of $25^{\circ} \mathrm{C}(198 \mathrm{U} / \mathrm{mL}), \mathrm{pH} 5(173 \mathrm{U} / \mathrm{mL})$, agitation speed $50 \mathrm{rpm}$ $(173 \mathrm{U} / \mathrm{mL})$ and incubation period of $96 \mathrm{~h}(102 \mathrm{U} / \mathrm{mL})$. Xylanase was produced maximally when birch wood xylan $(1 \% w / v)$ was used as the substrate at $25^{\circ} \mathrm{C}(1007 \mathrm{U} / \mathrm{mL}), \mathrm{pH} 10(2487 \mathrm{U} / \mathrm{mL})$, $200 \mathrm{rpm}(1814 \mathrm{U} / \mathrm{mL})$, and under an incubation period of $84 \mathrm{~h}(1296 \mathrm{U} / \mathrm{mL})$. Our findings showed that Micrococcus sp. SAMRC-UFH3 appears to be a potentially important candidate for lignocellulosic waste degradation and other relevant industrial applications.
\end{abstract}

Keywords: lignocellulosic biomass; Micrococcus sp. SAMRC-UFH3; culture conditions; cellulase; Xylanase

\section{Introduction}

Lignocellulose is the main structural constituent of woody plants and non-woody plants, such as grass, that constitutes a major source of renewable organic matter, comprised of lignin, hemicellulose, and cellulose [1]. The constituents of lignocellulosic materials are suitable substrates for biotechnological products of economic importance [2]. The bulk of lignocellulosic wastes are obtained from horticulture, industries of paper-pulp, timber, and other agro allied industries. Large quantities of lignocellulosic wastes are frequently disposed through burning, which is not a viable and sustainable disposal means [3].

Lignocellulolytic enzymes have numerous industrial applications in brewing and wine, chemicals, food, fuel, animal feed, pulp and paper, textile and laundry, and agriculture [3]. Cellulase is a complex enzyme system that plays an important role in the environment in the degradation of cellulose with subsequent conversion into useful products. It can also be utilized as a part of textile industry for "bio-cleaning" of fabrics and making stone washed look of denims, as well as in the household cleansers for enhancing fabric softness and brightness. It can also be used as part of cotton arrangements, wool, 
and coloring treatments, in effluent treatment, and pharmaceutical industries. Xylanase, just as with cellulase, plays a critical role in the degradation of plant biomass; hence, its production has attracted the attention of many researchers. It has various applications, incorporating biodegradation of lignocelluloses in food, animal feed, textiles, bio-deinking of waste paper, kraft pulp bleaching, and bio-pulping in the pulp and paper industry [4]. Xylanase is very important to pulp and paper industries because the hydrolysis of xylan encourages the removal of lignin from pulp and consequently diminish the utilization of chlorine as a bleaching agent [5]. Pulps derived during kraft pulping and waste paper deinking processes at high temperature and alkaline $\mathrm{pH}$ need novel microbial isolates with the ability to produce thermo-tolerant and alkalophilic xylanases $[6,7]$.

The search for potential sources of cellulolytic enzymes is continuing in the interest of successful bioconversion of lignocellulosic biomass. Several enzymes of fungal and bacterial origin have been evaluated for their ability to degrade cellulosic substrates into glucose monomers [8]. Cellulase-producing bacteria can be isolated and characterized from a variety of sources, such as soil, decayed plant materials, hot springs, organic matter, and feces of ruminants and composts [9]. Researchers are, however, continually searching for new microorganisms with higher cellulase activity [10]. Cellulase-producing microorganisms include; bacteria, yeast, and fungi [11-15]. One of the bacterial species that has been implicated in lignocellolytic and xylanolytic enzymes production is the genus of Micrococcus. Among the Micrococcus species, Micrococcus luteus is a Gram-positive, non-motile cocci, arranged in tetrads, non-spore forming, pigmented bacteria found in air, water, soil, and even on our skin. It can be a saprophytic or commensal microbe and sometimes acts as an opportunistic pathogen [16,17]. Micrococcus luteus has unique ways to remediate sites co-contaminated with metal and organic pollutants by compacting with these contaminants $[18,19]$. It also has the ability to degrade olefinic compounds and hydrocarbons [20].

The effective bio-conversion of cellulosic materials to value-added products mainly depends on the nature of cellulose, basis of cellulolytic enzymes and cultivation conditions [21]. There are several factors that positively influence the production of cellulase and such factors include; cellulose quality, air circulation, temperature, incubation period, carbon sources, composition, and $\mathrm{pH}$ of the medium [22]. In this study, we report on cellulase and xylanase production potential by a Micrococcus sp. SAMRC-UFH3 isolated from decaying biomass (sawdust) in the Eastern Cape Province, South Africa, as part of a larger study on the development of a bacterial consortium for the use in bioethanol production from biomass.

\section{Materials and Methods}

\subsection{Study Area and Sample Collection}

The decaying plant biomass (sawdust) samples were randomly and aseptically collected from different depths of a sawdust waste dump in a wood factory in Melani village in the Eastern Cape Province of South Africa. The samples were aseptically collected and placed in sterilized containers and later transported on ice packs to the laboratory for processing.

\subsection{Isolation of Cellulose and Xylan-Degrading Bacteria}

Isolation of cellulose and xylan-degrading bacteria was conducted, as described by Jeffrey et al. [23] with some modifications. About $1 \mathrm{~g}$ of the sawdust was mixed with $100 \mathrm{~mL}$ of sterile distilled water $\left(\mathrm{sdH}_{2} \mathrm{O}\right)$. The sawdust suspension was pre-treated at $55{ }^{\circ} \mathrm{C}$ for $15 \mathrm{~min}$ and later agitated vigorously below room temperature $\left(25 \pm 20^{\circ} \mathrm{C}\right)$ on an orbital shaker at $200 \mathrm{rpm}$ for $1 \mathrm{~h}$. A serial dilution of the suspension was carried out using sterile phosphate-buffered saline (PBS) and $100 \mu \mathrm{L}$ of the diluted suspension was spread on agar containing the growth media (M1 medium supplemented with nystatin $(50 \mathrm{mg} / \mathrm{L})$ and nalidixic acid $(25 \mathrm{mg} / \mathrm{L})$, and the plates were later incubated at $30^{\circ} \mathrm{C}$ for $7-14$ days depending on the colonies development. Subsequently, the bacterial colonies were selected based on their morphology, size, and colour and streaked again onto fresh 
M1 medium agar plates for purity and incubated further at $30^{\circ} \mathrm{C}$ for $7-14$ days. After purification, the colonies were compared visually to eliminate those with similar colonial characteristics and discrete colonies were sub-cultured again and the stock cultures were prepared from the pure colonies and later stored at $-80{ }^{\circ} \mathrm{C}$ in $20 \%$ glycerol stock until further use.

\subsection{Growth Media Compositions}

The growth media used in the study included M1 agar supplemented with nystatin ( $50 \mathrm{mg} / \mathrm{L})$ and nalidixic acid $(25 \mathrm{mg} / \mathrm{L})$ to retard fungal growth and Gram-negative bacteria, respectively. M1 agar contains yeast extract $5.0 \mathrm{~g} / \mathrm{L}$, protease peptone $0.5 \mathrm{~g} / \mathrm{L}$, casamino acids $0.5 \mathrm{~g} / \mathrm{L}$, glucose $0.5 \mathrm{~g} / \mathrm{L}$, soluble starch $0.5 \mathrm{~g} / \mathrm{L}$, dipotassium phosphate $0.3 \mathrm{~g} / \mathrm{L}$, magnesium sulfate $7 \mathrm{H}_{2} \mathrm{O} 0.5 \mathrm{~g} / \mathrm{L}$, sodium pyruvate $0.3 \mathrm{~g} / \mathrm{L}$, and agar $15 \mathrm{~g} / \mathrm{L}$. Luria Bertani (LB) broth contained tryptone $10 \mathrm{~g} / \mathrm{L}, \mathrm{NaCl} 10 \mathrm{~g} / \mathrm{L}$ and yeast extract $5 \mathrm{~g} / \mathrm{L}$. Basal medium was composed of carboxymethyl cellulose (CMC) $5 \mathrm{~g} / \mathrm{L}$, $\mathrm{NaNO}_{3} 1 \mathrm{~g} / \mathrm{L}, \mathrm{K}_{2} \mathrm{HPO}_{4} 1 \mathrm{~g} / \mathrm{L}, \mathrm{KCl} 1 \mathrm{~g} / \mathrm{L}, \mathrm{MgSO}_{4} 1 \mathrm{~g} / \mathrm{L}$, yeast extract $0.5 \mathrm{~g} / \mathrm{L}$ and agar $15 \mathrm{~g} / \mathrm{L}$ in distilled water. For basal medium containing xylan, CMC $(5 \mathrm{~g})$ was replaced with birch wood xylan (5 g) [24].

\subsection{Screening for Cellulase and Xylanase-Producing Bacteria}

The selected purified colonies were cultured on carboxymethyl cellulose (CMC) and xylan-containing basal media (XBM) prepared in accordance with the description of Pointing et al. [25]. Cellulolytic and xylanolytic bacteria were qualitatively identified using Gram's iodine stain $(0.25 \% \mathrm{w} / \mathrm{v}$ aqueous $\mathrm{I}_{2}$ and KI) solution [26]. The bacterial isolates were grown in $10 \mathrm{~mL}$ of LB broth for $24 \mathrm{~h}$ at $30^{\circ} \mathrm{C}$, with agitation at $200 \mathrm{rpm}$ and slow growing isolates were left to incubate for an additional $48 \mathrm{~h}$. The inocula were prepared from the fermented broths after standardizing to optical density 0.1 at $\mathrm{OD}_{600}$ and the activity of cellulase was determined by Gram's Iodine method [24]. M1 agar medium or basal media (BM) supplemented with CMC $(4 \% w / v)$ or xylan $(1.6 \% w / v)$ agar was prepared and sterilized by autoclaving at $121{ }^{\circ} \mathrm{C}$ for $15 \mathrm{~min}$. An aliquot $(5 \mu \mathrm{L})$ of standardized cultures were spread onto the agar plates containing carboxymethyl cellulase (CMC) or xylan basal medium and then incubated at $30^{\circ} \mathrm{C}$ for $48 \mathrm{~h}$. The plates were flooded with Gram's iodine solution (KI (2 g) and $\mathrm{I}_{2}$ $(1 \mathrm{~g})$ in $300 \mathrm{~mL}$ of distilled water) for $5 \mathrm{~min}$ and left in a sterilized laminar flow for $5 \mathrm{~min}$ in order to visualize cellulase and xylanase activities. After 72-96 h of incubation period, the formation of halo zone from the point of spot inoculation of the broth culture outwards indicates substrate (CMC or Xylan) degradation by the enzyme produced by the bacterial isolate. Degradation around the colonies appeared as a yellow-opaque zone against a blue colour for un-degraded CMC or xylan [26].

\subsection{Identification of the Bacterial Isolate by $16 S$ rRNA Gene Sequencing}

The bacterial isolate (PLY1) was identified by 16S rRNA gene nucleotide sequencing. The genomic DNA (deoxyribonucleic acid) used for the PCR was prepared from pure culture of the isolate PLY1 grown on nutrient agar at $30{ }^{\circ} \mathrm{C}$. The collective genomic DNA from the microscopic organisms was isolated utilizing the DNA purification Kit (Pure Fast ${ }^{\circledR}$ Bacterial Genomic DNA purification pack, Helini Bio atoms, India), as indicated by the manufacturer's protocol. The 16S rDNA gene fragment was amplified using general universal primers (Actino specific forward primer $5^{\prime}$-GCCTAACACATGCAAGTCGA-3' and Actino-specific reverse primer $3^{\prime}$-CGTATTACCGCGGCTGCTGG-5'. The conditions of the PCR were initialised with starting denaturation at $94{ }^{\circ} \mathrm{C}$ for $3 \mathrm{~min}$ removed after 30 cycles of enhancement (denaturation at $94{ }^{\circ} \mathrm{C}$ for $60 \mathrm{~s}$, annealing at $5{ }^{\circ} \mathrm{C}$ for $60 \mathrm{~s}$, and extension at $72{ }^{\circ} \mathrm{C}$ for $60 \mathrm{~s}$ ) trailed by certain expansion at $72{ }^{\circ} \mathrm{C}$ for $5 \mathrm{~min}$. The amplification reactions were carried out in a total volume of $50 \mu \mathrm{L}$ in a gradient PCR. The PCR product was visualized using $1 \%$ agarose gel and the fragment was purified (Helini Pure Fast PCR tidy up unit, Helini Bio particles, India) as indicated by the maker's guidelines and the band was visualized under UV Transilluminator (XD-79.WL/26MX, UVitec, Cambridge, UK). The direct sequencing of PCR product was performed by dideoxy chain end strategy utilizing ABI PRISM ${ }^{\circledR}$ 
3100-Avant Genetic Analyzer (Applied Biosystems, Foster City, CA, USA) at Inqaba Biotech South Africa. The results obtained were aligned with published $16 \mathrm{~S}$ rDNA sequences in the GenBank through a BLAST sequence tool from the National Centre for Biotechnology Information (NCBI) database (Bethesda, MD, USA) [27].

\subsection{Cellulase and Xylanase Production}

Enzyme production was carried out by submerged fermentation procedures in accordance with the method of Sharma and Bajaj [28], using basal salt medium containing CMC and birch wood xylan as carbon sources at a final concentration of $1 \%(w / v)$. The bacterial isolate was refreshed in basal salt medium supplemented with CMC or birch wood xylan and incubated for $48 \mathrm{~h}$. Two milliliters of the pre-culture were inoculated into $100 \mathrm{~mL}$ of production medium contained in Erlenmeyer flasks $(250 \mathrm{~mL})$ and incubated on a rotary shaker $200 \mathrm{rpm}$ at $45{ }^{\circ} \mathrm{C}$. The enzyme activity was assayed periodically at different time intervals. Two milliliters of the fermented broth was centrifuged at $10,000 \times \mathrm{g}$ for $5 \mathrm{~min}$ at $4{ }^{\circ} \mathrm{C}$ to obtain the supernatant that was for assaying cellulase and xylanase activities after appropriate dilutions [29].

\subsection{Cellulase and Xylanase Activity}

Cellulase and xylanase activities were measured as described by Swe [30]. After centrifugation, $0.2 \mathrm{~mL}$ of culture supernatant was added to $1.8 \mathrm{~mL}$ of $1 \% \mathrm{CMC} /$ xylan prepared in $0.05 \mathrm{M}$ phosphate buffer ( $\mathrm{pH} 7$ ) in a test tube and incubated at $40{ }^{\circ} \mathrm{C}$ for $30 \mathrm{~min}$. Three milliliters of dinitrosalicylic acid (DNS) reagent (1 $\mathrm{g}$ of 3,5-dinitrosallicylic acid in $20 \mathrm{~mL} 2 \mathrm{M} \mathrm{NaOH}$ ) was added to terminate the reaction and the tubes were placed in a water bath at $100{ }^{\circ} \mathrm{C}$ for $15 \mathrm{~min}$. Rochelle's salt solution $(1 \mathrm{~mL})$ was added to stabilize the color before determining absorbance at $575 \mathrm{~nm}$ with $0.05 \mathrm{M}$ phosphate buffer used as a blank. One unit of enzyme activity was defined as the measure of enzyme that released $1 \mu \mathrm{M}$ of glucose/xylose per min.

\subsection{Optimization of Culture Conditions for Enzyme Production}

\subsubsection{Effect of Temperature}

The effect of incubation temperature on cellulase and xylanase production was assessed at different temperatures, ranging from $25-50{ }^{\circ} \mathrm{C}$ in accordance to the method of Adhyaru et al. [10,31].

\subsubsection{Effect of Initial $\mathrm{pH}$ of Growth Medium}

The effect of initial $\mathrm{pH}$ of the growth medium on cellulase or xylanase production was examined by varying the $\mathrm{pH}$ from 3-11. The $\mathrm{pH}$ was adjusted by using $1 \mathrm{M} \mathrm{HCl}$ or $\mathrm{NaOH}$ prior to autoclaving [31].

\subsubsection{Effect of Agitation Speed}

The effect of the rate of agitation on cellulase or xylanase production was assessed at 0-200 rpm at $50 \mathrm{rpm}$ intervals [31].

\subsection{Time Course for Cellulase and Xylanase Production}

In order to achieve maximum cellulase or xylanase production, optimum growth conditions were used over an incubation period of $108 \mathrm{~h}$. The crude enzyme was extracted and assayed at regular intervals of $6 \mathrm{~h}$ [31].

\subsection{Data Analysis}

The experimental data was expressed as mean \pm standard deviation (SD) of the three replicates. Statistical analysis was done by using MINITAB program (version 12 for windows (Minitab Inc., State 
College, PA, USA). One-way analysis of variance (ANOVA) was used to compare the data among the cellulase and xylanase fractions with the control. $p<0.05$ was considered statistically significant.

\section{Results}

\subsection{Isolation and Screening for Cellulase and Xylanase Activity}

In this study, cellulase and xylanase-producing bacterial isolates were obtained from sawdust samples/wood shavings from Melani village around Alice Town in the Eastern Cape Province of South Africa. Cellulolytic and xylanolytic bacteria were presumptively identified by the qualitative plate assay method. The sample was pre-heated and, in addition, M1 agar was supplemented with nalidixic acid and nystatin to reduce the growth of other microorganisms. Although phenology is not an accurate way to separate colonies, the bacterial isolates were selected and further purified based on the morphological characteristics on the agar plate. In this study, a total of 58 bacterial isolates were obtained from wood shavings and nine isolates with marked distinct colony characteristics were screened for cellulose degradation. Seven of these isolates were positive when cellulose was used as a sole carbon source, whereas three isolates were able to degrade xylan as the sole source of carbon.

Cellulase and xylanase activities were indicated by the halo zones around the colonies. The diameters of halo zones were measured and the results are depicted in Table 1. Of all positive isolates, PLY1, MLY10, and TLY3 showed both xylanase and cellulase activities; however, PLY1 was chosen for further work based on its highest cumulative activity (114 mm; Table 1).

Table 1. Summary of the relative potentials of the bacterial isolates for cellulase and xylanase production.

\begin{tabular}{cccc}
\hline Isolate Code & $\begin{array}{c}\text { Halo Zone Diameter } \\
(\mathbf{m m} \pm \mathbf{S D}) \text { on CMC }\end{array}$ & $\begin{array}{c}\text { Halo Zone Diameter } \\
(\mathbf{m m} \pm \mathbf{S D}) \text { on Xylan }\end{array}$ & $\begin{array}{c}\text { Halo Zone Diameter of the } \\
\text { Two Enzymes } \mathbf{( m m} \pm \mathbf{S D})\end{array}$ \\
\hline PLY1 & $\mathbf{7 1} \pm \mathbf{7 . 5}$ & $\mathbf{4 3} \pm \mathbf{3 . 5 8}$ & $\mathbf{1 1 4}$ \\
BLY2 & $11.6 \pm 2.7$ & - & 11.6 \\
BLY10 & $11.4 \pm 1.8$ & - & 11.4 \\
BLC6 & $22.2 \pm 2.4$ & $40.7 \pm 4.7$ & 22.2 \\
MLY10 & $72.7 \pm 6.4$ & - & 113.4 \\
TLW8 & - & - & 0 \\
TLY1 & $12.5 \pm 4.4$ & $58.7 \pm 3.2$ & 12.5 \\
TLY3 & $32.7 \pm 4.7$ & & 91.4 \\
\hline
\end{tabular}

\subsection{Identification of the Bacterial Isolates by $16 S$ rRNA Gene Nucleotide Sequencing}

Basic Local Alignment Search Tool (BLAST) results of the 16S rRNA gene nucleotide sequence of PLY1 revealed it to have $98 \%$ similarity to Micrococcus luteus strain Fse9 and the sequence was deposited in GenBank as Micrococcus luteus strain SAMRC-UFH3 with accession number KU171371.

\subsection{Optimization of Culture Conditions for Enzymes Production by Micrococcus sp. SAMRC-UFH3}

\subsubsection{Effect of Temperature on Cellulase and Xylanase Production}

The effect of temperature on cellulase and xylanase production by the test bacteria was investigated and the results are shown in Figure 1a,b. It was observed that the optimal temperature for cellulase activity was $25^{\circ} \mathrm{C}$ with enzyme activity of $198 \mathrm{U} / \mathrm{mL}$ (Figure 1) and cellulase activity decreased with increasing temperature until $40{ }^{\circ} \mathrm{C}$ after which a gradual increase was observed up to $50{ }^{\circ} \mathrm{C}$. On the other hand, optimal temperature for xylanase production was achieved at $25^{\circ} \mathrm{C}$ with enzyme activity of $1007 \mathrm{U} / \mathrm{mL}$ (Figure 2). As temperature increased from $25^{\circ} \mathrm{C}$, xylanase activity declined to about $650 \mathrm{U} / \mathrm{mL}$ at $45^{\circ} \mathrm{C}$ and then increased to about $765 \mathrm{U} / \mathrm{mL}$ at $50{ }^{\circ} \mathrm{C}$ (Figure 2). 


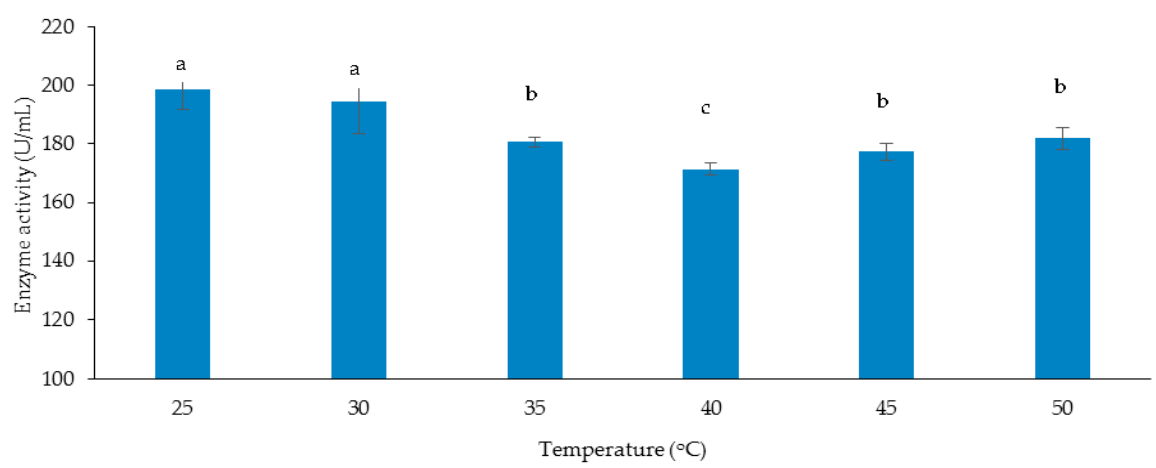

Figure 1. Effect of temperature on cellulase production by Micrococcus sp. SAMRC-UFH3. Data are presented as mean $\pm \mathrm{SD}$ of three replicates. Bar graphs with different letters shows significant difference $(p<0.05)$.

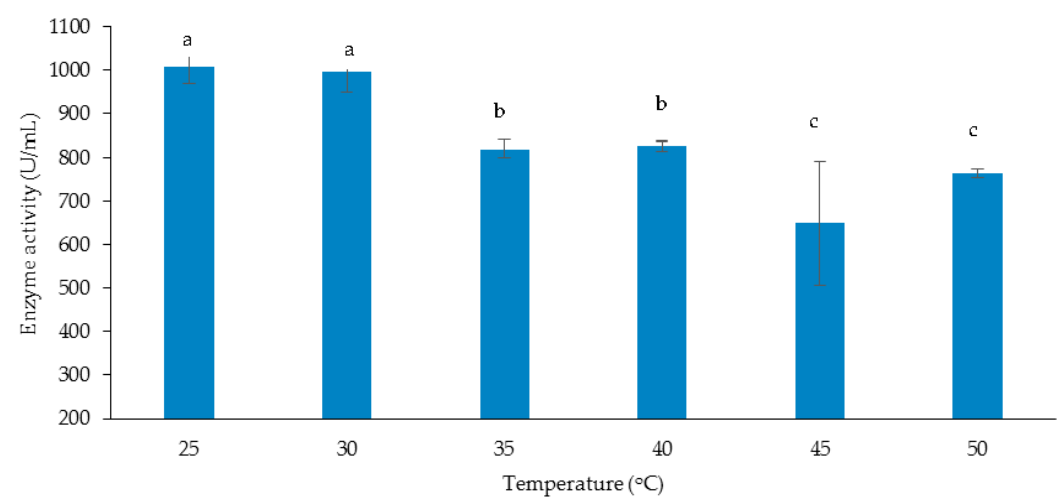

Figure 2. Effect of temperature on xylanase production by Micrococcus sp. SAMRC-UFH3. Data are presented as mean $\pm \mathrm{SD}$ of three replicates. Bar graphs with different letters show significant difference $(p<0.05)$.

\subsubsection{Effect of Initial pH of Growth Medium on Cellulase and Xylanase Production}

The effect of initial $\mathrm{pH}$ of growth medium on cellulase and xylanase production by Micrococcus sp. SAMRC-UFH3 was assessed over an extensive $\mathrm{pH}$ range of $3-11$. The optimum $\mathrm{pH}$ for cellulase production was $\mathrm{pH} 5$ with enzyme activity of $173 \mathrm{U} / \mathrm{mL}$ (Figure 3), while for xylanase production, the optimum $\mathrm{pH}$ was observed to be $\mathrm{pH} 10$ with enzyme activity of $2487 \mathrm{U} / \mathrm{mL}$ (Figure 4).

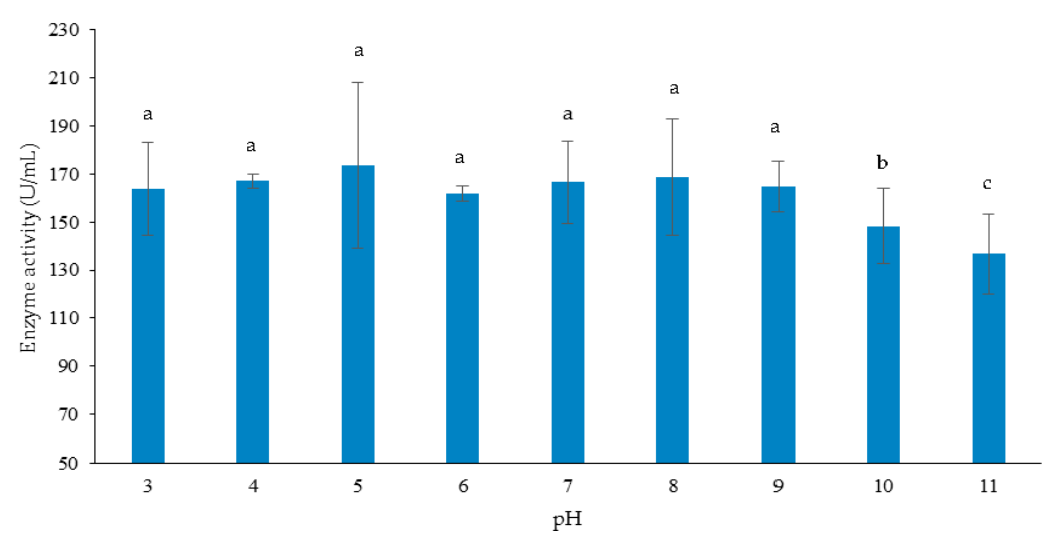

Figure 3. Effect of initial $\mathrm{pH}$ of growth medium on cellulase production by Micrococcus sp. SAMRC-UFH3. Data are presented as mean $\pm \mathrm{SD}$ of three replicates. Bar graphs with different letters show significant difference $(p<0.05)$. 


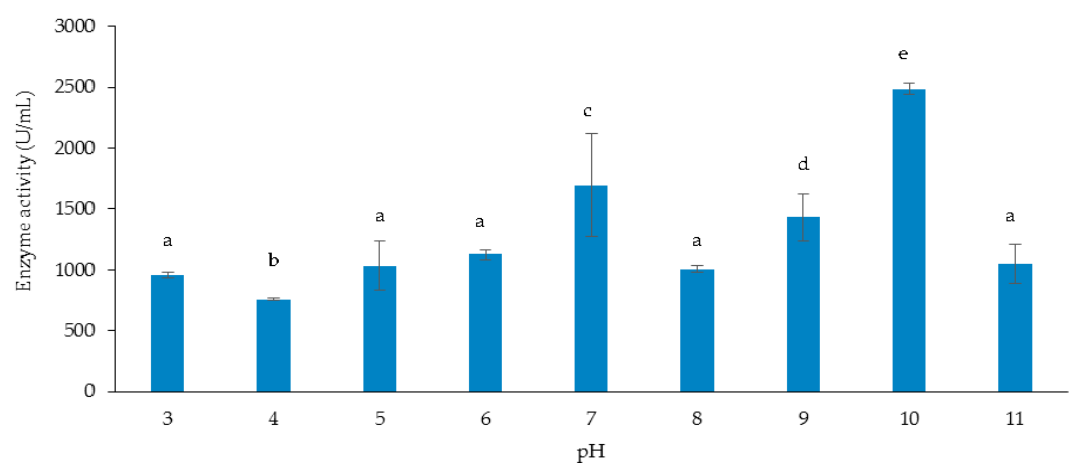

Figure 4. Effect of initial $\mathrm{pH}$ of growth medium on xylanase production by Micrococcus sp. SAMRC-UFH3. Data are presented as mean \pm SD of three replicates. Bar graphs with different letters show significant difference $(p<0.05)$.

\subsubsection{Effect of Agitation Speed on Cellulase and Xylanase Production}

With respect to the effect of agitation rate on the enzyme production by Micrococcus sp. SAMRC-UFH3, no appreciable difference between static and $50 \mathrm{rpm}$ for cellulase production was observed, although the highest activity was obtained at $50 \mathrm{rpm}$ with activity of $173 \mathrm{U} / \mathrm{mL}$ (Figure 5). Further increase in agitation speed resulted in a decrease of activity with the lowest activity recorded at $200 \mathrm{rpm}$. For xylanase production, activity $(1814 \mathrm{U} / \mathrm{mL}$ ) was optimal at 200 (Figure 6).

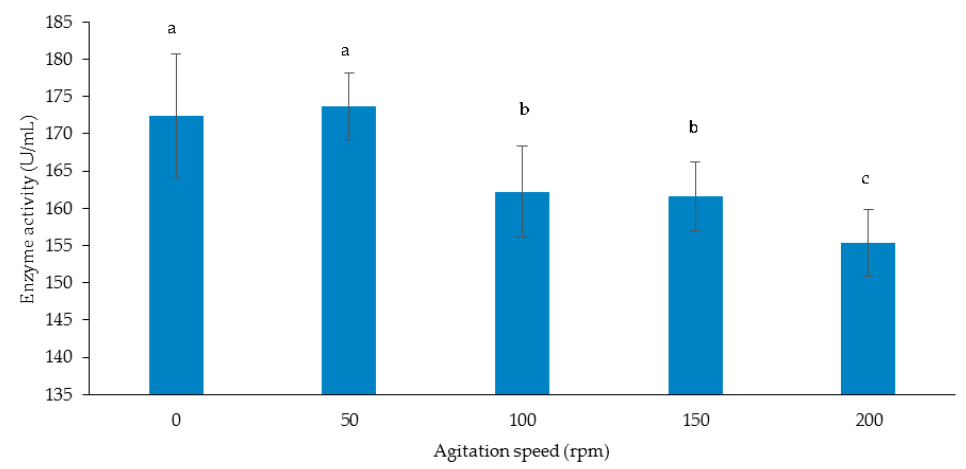

Figure 5. Effect of agitation speed on cellulase production by Micrococcus sp. SAMRC-UFH3. Data are presented as mean \pm SD of three replicates. Bar graphs with different letters show significant difference $(p<0.05)$.

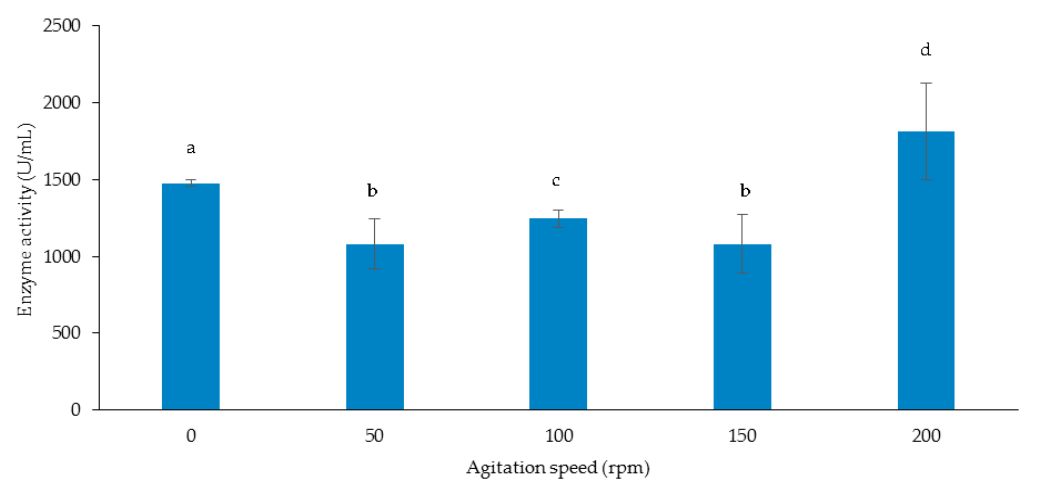

Figure 6. Effect of agitation speed on xylanase production by Micrococcus sp. SAMRC-UFH3. Data are presented as mean $\pm \mathrm{SD}$ of three replicates. Bar graphs with different letters show significant differences $(p<0.05)$. 


\subsection{Time Course of Cellulase and Xylanase Production}

Optimum growth conditions for Micrococcus sp. SAMRC-UFH3 were used to carry out a time course assay of cellulase and xylanase production over an incubation period of $108 \mathrm{~h}$. Results presented in Figure 7 show that cellulase production progressively increased for the first $14-16 \mathrm{~h}$, and remained relatively constant thereafter for the next $60 \mathrm{~h}$, attaining maximum activity of $102 \mathrm{U} / \mathrm{mL}$ at $96 \mathrm{~h}$ before declining at $108 \mathrm{~h}$. Xylanase production increased progressively and peaked at $84 \mathrm{~h}$ attaining maximum enzyme activity of $1296 \mathrm{U} / \mathrm{mL}$ followed by a rapid decline over the next $24 \mathrm{~h}$ (Figure 8).

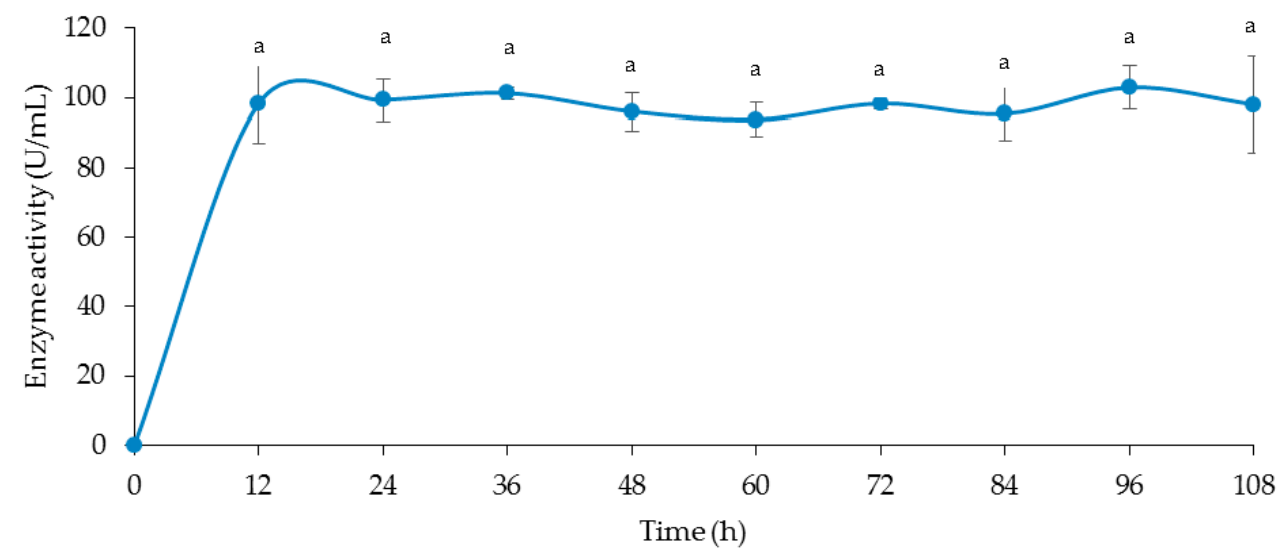

Figure 7. Time course assay of cellulase production by Micrococcus sp. SAMRC-UFH3 using CMC as the substrate. Data are presented as mean $\pm \mathrm{SD}$ of three replicates. The same letter shows that there is no significant difference for all the treatment cases $(p>0.05)$.

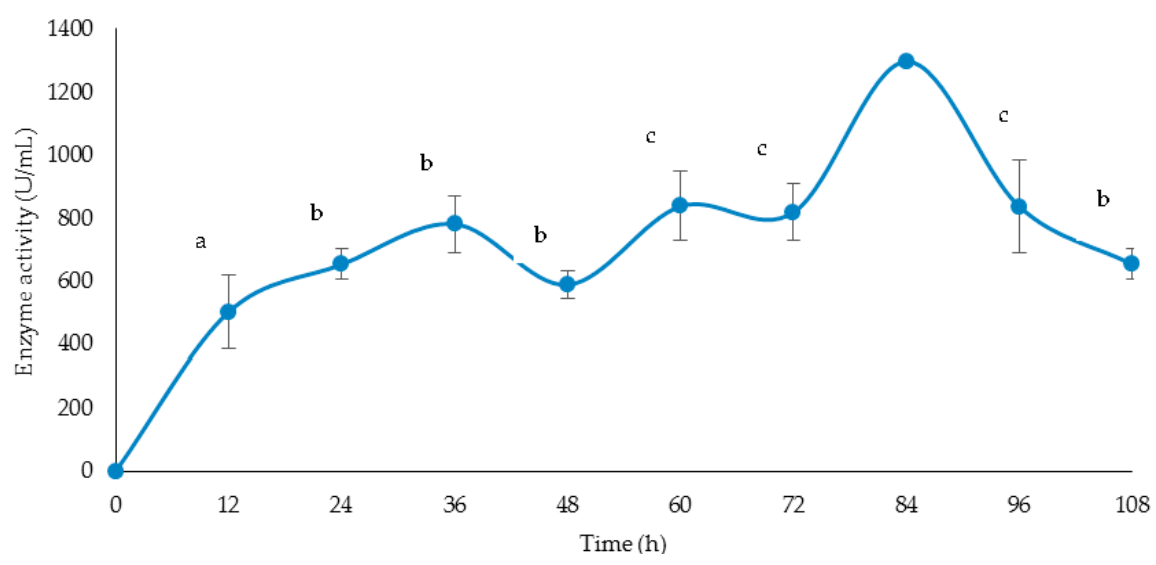

Figure 8. Time course assay for xylanase production by Micrococcus sp. SAMRC-UFH3 using xylan as the substrate. Data are presented as mean \pm SD of three replicates. Graphs with different letters show significant difference $(p<0.05)$.

\section{Discussion}

Lignocellulosic biomass is an alternative and cost effective resource for the production of biofuels due to its abundance and renewability [32]. Sources for lignocellulosic biomass include, among others, leaves, stems, and stalks from sources such as corn fiber, corn stover, sugarcane bagasse, rice hulls, woody crops, and forest residues. In the technologies for effectively converting cellulosic biomass to fermentable sugars, cellulases are regarded as one of the key elements.

Cellulases have a wide range of applications, such as in food, brewery, wine, pulp and paper, textile, detergent, feed, and agriculture. Cellulases are also used in the textile industry for bio-polishing of fabrics and making the stone-washed look of denims and in household laundry detergents for 
improving fabric softness and brightness. Cellulases are used in cotton preparations, wool and dyeing treatments, in effluent treatment, and also in pharmaceutical industries [17].

Potential applications of xylanases include the bioconversion of lignocellulosic material and agro-wastes to fermentative products, clarification of juices, improvement in the consistency of beer, and the digestibility of animal feed stock [4]. The application of xylanase in the saccharification of xylan in agro-wastes and agro-foods intensifies the need for exploiting the potential role of them in biotechnology.

Cellulolytic and xylanolytic enzymes are synthesized by a number of microorganisms. Among the microbes, bacteria are more reliable due to their adaptability to different environmental conditions, relatively fast growth than any other microbes and extremely have the capacity to produce highly stable enzymes complement which serves as highly potent sources of individually important enzymes [33,34]. The study focused on the isolation and screening of bacteria from sawdust samples collected from Melani Village (wood factory) with promising cellulose and xylan-degrading potentials for modification and decomposition of lignocellulosic biomass for industrial application.

Micrococcus sp. SAMRC-UFH3 was found to degrade both cellulose and xylan (Table 1) to varying degrees as shown by different halo zone diameter measurements after staining with Gram's iodine solution. Cellulose was the preferred substrate with $71 \mathrm{~mm}$ halo zone diameter on CMC supplemented agar medium compared to xylan that had a smaller halo zone diameter of $43 \mathrm{~mm}$ on birch wood xylan agar. However, despite the larger halo zone in cellulose-supplemented medium compared to xylan-supplemented medium, the hydrolytic action of these enzymes is not a reflection of the size of the halo zone but depends on the environment from which they are isolated [35]. This is an indication that the test bacteria have the possibility to secrete a wide variety of enzymes, which may assist natural selection of the microorganisms to survive in a competitive environment [23]. The relative hydrolytic capability of the enzymes produced by the bacterial isolates went from weak; moderate to strong depending upon the diameter of the clear zones of hydrolysis enclosed surrounding the colonies in the screening process [36].

Degradation of cellulosic materials is a multifaceted process and several microbial cellulolytic enzymes are required [37]. Cellulose and hemicellulose can be degraded by chemical hydrolysis (using acids or alkali) or enzymatic hydrolysis. Several methods of acid hydrolysis using sulphuric or hydrochloric acid at varying concentrations, temperatures, and pressures have been used in the industry for lignocellulose degradation $[38,39]$. The degradation of lignocellulosic materials involves a complex depolymerisation process of the polysaccharide components into sugar monomers that requires several different types of enzymes [40]. Enzymes known as cellulases are responsible for the breakdown of cellulose into glucose monomers.

The microbial production of enzymes depends on the genetic nature of the organism, the physio-chemical parameters, the fermentation medium components and their concentrations. Thus, optimization of the culture conditions is important to achieve maximum yields and to produce a compelling bioprocess framework for industrial applications. Therefore, a judicious selection of these parameters can dramatically improve the enzyme yield. Several authors have reported increased enzyme yield upon optimization of bioprocess conditions [22,41-43].

Cellulase systems consist of endoglucanases, exoglucanase, and $\beta$-glucosidase; the synergy of all these enzymes enables the hydrolysis of cellulose to glucose to be made possible [44]. Nutrient sources were found to be the important factor for the cellulase production. Since carbon is considered as the primary nutrient for the bacteria [45], carboxymethyl cellulose (CMC), and xylan were utilized for the cellulase and xylanase production, respectively, in this study.

It has been reported that temperature has an effect on the activity of both cellulase and xylanase produced by Micrococcus sp. SAMRC-UFH3 [46]. In our current study, maximum production of both cellulase $(198 \mathrm{U} / \mathrm{mL})$ and xylanase $(1007 \mathrm{U} / \mathrm{mL})$ were observed at $25^{\circ} \mathrm{C}$ by the test bacteria (Figures 1 and 2). The temperature was found to influence extracellular enzyme secretion, possibly by changing the physical properties of the cell membrane. On the contrary, the optimum temperature 
for maximum growth of Bacillus subtilis 115 and Bacillus subtilis for cellulase production was reported at $40{ }^{\circ} \mathrm{C}$ [47]. According to the report documented by Ray et al. [10], the minimum cellulase yield was observed when fermentation was carried out at $45^{\circ} \mathrm{C}$, while maximum yield was obtained at $40{ }^{\circ} \mathrm{C}$ by both Bacillus subtilis and Bacillus circulans. Nandimath et al. [32] reported that Pseudomonas sp. produced maximum cellulase production at $30^{\circ} \mathrm{C}$. These findings do not differ significantly from those documented by Bakare et al. [48] who found that the cellulase enzyme produced by Pseudomonas fluorescens was activated at 30 to $35{ }^{\circ} \mathrm{C}$ and peaked at $35^{\circ} \mathrm{C}$. Geobacillus sp. T1 could not grow at temperatures less than $40^{\circ} \mathrm{C}$, but at temperatures ranging from $40-60{ }^{\circ} \mathrm{C}$, this bacterium grew well, showing increased cellulase activity. Geobacillus sp. T1 on the other hand, produced cellulase optimally at $50{ }^{\circ} \mathrm{C}$ [49]. Several reported studies indicate varying temperature optimal for the production of both cellulase and xylanase by different microorganisms. Abdel-Fattah et al. [50] recorded maximum cellulase activity at $55{ }^{\circ} \mathrm{C}$ for a thermophilic Geobacillus strain isolated from soil, whereas, Monisha et al. [51] and Sepahy et al. [52] reported optimum temperature of $37^{\circ} \mathrm{C}$ for xylanase production by both B. pumilus and B. mojavensis AG137, respectively, in submerged fermentation. On the hand other, different strains of Bacillus sp. gave a maximum yield of xylanase production at incubation temperatures of $45^{\circ} \mathrm{C}$ and $55^{\circ} \mathrm{C}$ [53].

The $\mathrm{pH}$ of the fermentation medium is reported to impact the growth of any microbial strain and consequent metabolic product formation [54]. In addition, many enzymatic processes and the transport of various components across the cell membrane are strongly affected by the $\mathrm{pH}$ of the medium [55]. A optimum $\mathrm{pH}$ is required to maintain the three-dimensional shape of the active site of enzymes and the change in $\mathrm{pH}$ results in a loss of functional shape of the enzyme due to alterations in the ionic bonding of the enzyme. In our study, cellulase and xylanase production by Micrococcus sp. SAMRC-UFH3 under submerged fermentation conditions was monitored over $\mathrm{pH}$ ranging from 3-11. The results presented in Figures 3 and 4 suggest that the $\mathrm{pH}$ of the fermentation medium influences enzyme production. Hence, the maximal production for cellulase was observed at pH 5 (173 U/L). Xylanase production was optimum at $\mathrm{pH} 10$ with enzyme activity of $2487 \mathrm{U} / \mathrm{mL}$. In another study reported by Nandimath et al. [32], cellulase was found to be produced effectively within $60 \mathrm{~min}$ and at $\mathrm{pH}$ 5. Liang et al. [56] further noted that growth medium $\mathrm{pH}$ strongly influences many enzymatic reactions by affecting the transport of a number of chemical products and enzymes across the cell membrane. For example, for the production of cellulase by Bacillus subtilis and Bacillus circulans, initial $\mathrm{pH}$ of growth medium in the range of 7-7.5 was found to be optimum [6]. The optimum $\mathrm{pH}$ for the maximum cellulase production by both Bacillus sp. 8 and Bacillus sp. 17 was found to be 7 [57]. The maximum CMCase activity of $0.29 \mathrm{IU} / \mathrm{mL}$ was reported in a study on cellulase production by Bacillus sp. at $\mathrm{pH} 7$ [58]. From previous studies, only few xylanases have been reported to be active and stable at alkaline $\mathrm{pH}$ and high temperatures $[59,60]$. Increase or decrease in the $\mathrm{pH}$ of the medium resulted in declined enzyme production. Pereira et al. [61] and Park et al. [62] suggested that the alteration in $\mathrm{pH}$ tolerance observed during xylanase production might be due to different enzyme mixtures secreted and/or the post-translational alterations in the xylanase secretion procedure; for example, glycosylation enhancing reliability in extreme $\mathrm{pH}$ and temperature conditions. Xylanase can also be further categorized as facultative alkaliphiles. At $\mathrm{pH} 6$, cellulase gradually decreased while xylanase at $\mathrm{pH} 11$ significantly lost activity with only $34 \%$ retained [63]. In a published report of Sepahy et al. [52], an optimum $\mathrm{pH}$ of 8 was observed for xylanase production by B. mojavensis AG137 in submerged fermentation while Simphiwe et al. [53] reported eight different strains of Bacillus sp. showing maximum xylanase production at $\mathrm{pH} 8$ whereas, Bacillus pumilus showed maximum xylanase production at $\mathrm{pH} 7$ [51].

The result of agitation on cellulase and xylanase production by Micrococcus sp. SAMRC-UFH3 was investigated (Figures 5 and 6). Agitation has been reported to affect the level of aeration and mixing of the nutrients in the fermentation medium [64]. Maximum cellulase production was recorded at $50 \mathrm{rpm}$ with enzyme activity of $173 \mathrm{U} / \mathrm{mL}$ (Figure 5). The report of EI-Refai et al. [65] concurs with our findings in which the best agitation rate for cellulase was found to be between 0 and $50 \mathrm{rpm}$. In the 
present study, $200 \mathrm{rpm}$ proved to be the optimum agitation rate for xylanase production by the bacteria with activity of $1814 \mathrm{U} / \mathrm{mL}$ recorded (Figure 6). Kokare [66] reported that agitation at 150-200 rpm was found to be the most suitable for xylanase production by Micrococcus sp.

Time course experimentation was carried out to monitor the rate of cellulase and xylanase production by Micrococcus sp. SAMRC-UFH3 under optimum growth conditions. Results presented in Figure 7 indicate that cellulase production increased progressively until $96 \mathrm{~h}$ (Figure 8), when maximum enzyme production of $(102 \mathrm{U} / \mathrm{mL})$ was recorded. Our observation corroborates the report of Nagendra et al. [67], who noticed that the optimum incubation period for cellulase was also within $96 \mathrm{~h}$ in the late stationary phase of growth. In another study carried out on B. pumilus EB3 by Ariffin et al. [68], lower CMCase activity $(0.079 \mathrm{IU} / \mathrm{mL})$ was recorded after $24 \mathrm{~h}$ of incubation. In the case of xylanase production, the activity was found to be maximal $(1296 \mathrm{U} / \mathrm{mL})$ at $84 \mathrm{~h}$ (Figure 8). According to the findings of Sharma et al. [69], a shorter fermentation period was documented for xylanase production at stationary phase of growth by $\mathrm{G}$. thermoleovorans. The xylanase titer did not significantly increase, but a peak in production was attained in $42 \mathrm{~h}$ instead of $72 \mathrm{~h}$. The enzyme production pattern was consistent with that shown by Bacillus sp. when grown in a fermenter. Similarly, Mrudula and Shyam [70] reported a shorter incubation period of $48 \mathrm{~h}$ for maximum production of xylanase from B. megaterium MTTC 2444. In another study, some strains of Bacillus showed maximum xylanase production after $24 \mathrm{~h}$ using digested bran and $48 \mathrm{~h}$ of fermentation using sawdust as substrates, respectively [53]. Gupta and Kar [71] undertook studies on xylanase production by Bacillus sp. and reported that maximum xylanase production was observed in $48 \mathrm{~h}$ and $72 \mathrm{~h}$ using wheat bran and corn cob as substrates, respectively. Sepahy et al. [52] reported a fermentation period of $48 \mathrm{~h}$ by Bacillus mojavensis AG137 in submerged fermentation using oat bran as a substrate. Murugan et al. [72] reported $96 \mathrm{~h}$ as optimum fermentation period for xylanase production by Arthrobacter sp. MTCC 6915 in SSF using sawdust as a substrate.

\section{Conclusions}

Cellulase and xylanase yields appear to depend on a complex relationship involving a variety of factors, like inoculum size, $\mathrm{pH}$ value, temperature, and presence of inducers, aeration, growth time, and so forth. Only a few studies have been reported on cellulase and xylanase production by member of the genus of Micrococcus. The optimum conditions for maximum cellulase and xylanase production by Micrococcus sp. SAMRC-UFH3 was at 1\% of carboxymethyl cellulose (CMC) and birch wood xylan as a sole carbon source, respectively. The test bacteria produced cellulase optimally at $\mathrm{pH} 5,25^{\circ} \mathrm{C}$, $50 \mathrm{rpm}$, and at after $96 \mathrm{~h}$ of incubation period, while for xylanase maximum production was optimal at $\mathrm{pH} 10,25{ }^{\circ} \mathrm{C}, 200 \mathrm{rpm}$, and at after $84 \mathrm{~h}$ incubation period. By using these growth conditions, industrial production of cellulase and xylanase is reliable with Micrococcus sp. SAMRC-UFH3 in the future with the cheapest input rate. The test bacterial strain is non-pathogenic and easily growing organism under these characteristics it is suitable for large scale and small scale production. Further studies are in progress in our research group for the purification and application of cellulase in different commercial fields.

Acknowledgments: We are grateful to the National Research Foundation (NRF) of South Africa, the Medical Research Council of South Africa; and University of Fort Hare for their financial supports.

Author Contributions: All authors contributed to the work presented in this paper, Z.M. executed the research and collated the data; K.O. drafted the first manuscript; U.U.N. supervised the research and interpreted the data; L.V.M. and A.I.O. conceptualized and prepared the final manuscript draft.

Conflicts of Interest: The authors declare no conflict of interest.

\section{References}

1. Kumar, R.; Singh, S.; Singh, O.V. Bioconversion of lignocellulosic biomass: Biochemical and molecular perspectives. J. Ind. Microbiol. Biotechnol. 2008, 35, 377-391. [CrossRef] [PubMed] 
2. Sánchez, C. Lignocellulosic residues: Biodegradation and bioconversion by fungi. Biotechnol. Adv. 2009, 27, 185-194. [CrossRef] [PubMed]

3. Howard, R.L.; Abotsi, E.; Van Rensburg, E.J.; Howard, S. Lignocellulose biotechnology: Issues of bioconversion and enzyme production. Afr. J. Biotechnol. 2004, 2, 602-619. [CrossRef]

4. Subramaniyan, S.; Prema, P. Biotechnology of microbial xylanases: Enzymology, molecular biology, and application. Crit. Rev. Biotechnol. 2002, 22, 33-64. [CrossRef] [PubMed]

5. Techapun, C.; Charoenrat, T.; Watanabe, M.; Sasaki, K.; Poosaran, N. Optimization of thermostable and alkaline-tolerant cellulase-free xylanase production from agricultural waste by thermotolerant Streptomyces sp. Ab106, using the central composite experimental design. Biochem. Eng. J. 2002, 12, 99-105. [CrossRef]

6. Ghatora, S.K.; Chadha, B.S.; Badhan, A.K.; Saini, H.S.; Bhat, M.K. Identification and characterization of diverse xylanases from thermophilic and thermotolerant fungi. Bioresour. Technol. 2007, 1, 18-33.

7. Kulkarni, N.; Rao, M. Application of xylanase from alkaliphilic thermophilic Bacillus sp. NCIM 59 in bioleaching of bagasse pulp. J. Biotechnol. 1996, 51, 167-173. [CrossRef]

8. Yu, H.; Zeng, G.; Huang, H.; Xi, X.; Wang, R.; Huang, D.; Huang, G.; Li, J. Microbial community succession and lignocellulose degradation during agricultural waste composting. Biodegradation 2007, 18, 793-802. [CrossRef] [PubMed]

9. Doi, R.H. Cellulases of mesophilic microorganisms-Cellulosome and non-cellulosome producers. Incred. Anaerob. Physiol. Genom. Fuels 2008, 1125, 267-279.

10. Ray, A.K.; Bairagi, A.; Ghosh, K.S.; Sen, S.K. Optimization of fermentation conditions for cellulase production by Bacillus subtilis CY5 and Bacillus circulans TP3 isolated from fish gut. Acta Ichthyol. Piscat. 2007, 1, 47-53. [CrossRef]

11. Bischoff, K.M.; Rooney, A.P.; Li, X.L.; Liu, S.; Hughes, S.R. Purification and characterization of a family 5 endoglucanase from a moderately thermophilic strain of Bacillus licheniformis. Biotechnol. Lett. 2006, 28, 1761-1765. [CrossRef] [PubMed]

12. Camassola, M.; De Bittencourt, L.R.; Shenem, N.T.; Andreaus, J.; Dillon, A.J.P. Characterization of the cellulase complex of Penicillium echinulatum. Biocatal. Biotransform. 2004, 22, 391-396. [CrossRef]

13. Haakana, H.; Miettinen-Oinonen, A.; Joutsjoki, V.; Mäntylä, A.; Suominen, P.; Vehmaanperä, J. Cloning of cellulase genes from Melanocarpus albomyces and their efficient expression in Trichoderma reesei. Enzyme Microb. Technol. 2004, 34, 159-167. [CrossRef]

14. Silva, R.D.; Lago, E.S.; Merheb, C.W.; Macchione, M.M.; Park, Y.K.; Gomes, E. Production of xylanase and CMCase on solid state fermentation in different residues by Thermoascus aurantiacus miehe. Braz. J. Microbiol. 2005, 36, 235-241. [CrossRef]

15. Semêdo, L.T.; Gomes, R.C.; Bon, E.P.; Soares, R.M.; Linhares, L.F.; Coelho, R.R. Endocellulase and exocellulase activities of two Streptomyces strains isolated from a forest soil. In Twenty-First Symposium on Biotechnology for Fuels and Chemicals; Humana Press: New York, NY, USA, 2000; pp. 267-276.

16. Doddamani, H.P.; Ninnekar, H.Z. Biodegradation of carbaryl by a Micrococcus species. Curr. Microbiol. 2001, 43, 69-73. [CrossRef] [PubMed]

17. Nisha, P.; Das, A.; Saritha, K.V. Production of cellulase from Micrococcus sp. and effect of growth parameters. 2014, 2, 236-240.

18. Sandrin, T.R.; Maier, R.M. Impact of metals on the biodegradation of organic pollutants. Environ. Health Perspect. 2003, 111, 1093-1101. [CrossRef] [PubMed]

19. Young, K.S.; de Abreu, C.N. (Eds.) Internet Addiction: A Handbook and Guide to Evaluation and Treatment; John Wiley \& Sons, Inc.: Hoboken, NJ, USA, 2010.

20. Zhuang, L.; Wai, J.S.; Embrey, M.W.; Fisher, T.E.; Egbertson, M.S.; Payne, L.S.; Guare, J.P.; Vacca, J.P.; Hazuda, D.J.; Felock, P.J.; et al. Design and synthesis of 8-hydroxy-[1,6] naphthyridines as novel inhibitors of HIV-1 integrase in vitro and in infected cells. J. Med. Chem. 2003, 46, 453-456. [CrossRef] [PubMed]

21. Alam, M.Z.; Manchur, M.A.; Anwar, M.N. Isolation, purification, characterization of cellulolytic enzymes produced by the isolate Streptomyces omiyaensis. Pak. J. Biol. Sci. 2004, 7, 1647-1653.

22. Immanuel, G.; Dhanusha, R.; Prema, P.; Palavesam, A. Effect of different growth parameters on endoglucanase enzyme activity by bacteria isolated from coir retting effluents of estuarine environment. Int. J. Environ. Sci. Technol. 2006, 3, 25-34. [CrossRef]

23. Jeffrey, L.S.H. Isolation, characterization and identification of actinomycetes from agriculture soils at Semongok, Sarawak. Afr. J. Biotechnol. 2008, 7, 3697-3702. 
24. Kasana, R.C.; Salwan, R.; Dhar, H.; Dutt, S.; Gulati, A. A rapid and easy method for the detection of microbial cellulases on agar plates using Gram's iodine. Curr. Microbiol. 2008, 57, 503-507. [CrossRef] [PubMed]

25. Pointing, S.B. Qualitative methods for the determination of lignocellulolytic enzyme production by tropical fungi. Funngal Divers. 1999, 2, 17-33.

26. Teather, R.M.; Wood, P.J. Use of Congo red-polysaccharide interactions in enumeration and characterization of cellulolytic bacteria from the bovine rumen. Appl. Environ. Microbiol. 1982, 43, 777-780. [PubMed]

27. Mangamuri, U.K.; Muvva, V.; Poda, S.; Kamma, S. Isolation, identification and molecular characterization of rare actinomycetes from mangrove ecosystem of Nizampatnam. Malays. J. Microbiol. 2012, 8, 83-91.

28. Sharma, P.; Bajaj, B.K. Production and partial characterization of alkali-tolerant xylanase from an alkalophilic Streptomyces sp. CD3. J. Sci. Industr. Res. 2005, 64, 688-697.

29. Bajaj, B.K.; Khajuria, Y.P.; Singh, V.P. Agricultural residues as potential substrates for production of xylanase from alkali-thermo-tolerant bacterial isolate. Biocat. Agric. Biotechnol. 2012, 1, 314-320.

30. Swe, K.T. Screening Potential Lignin-Degrading Microorganisms and Evaluating Their Optimal Enzyme Producing Growth Conditions; Chalmers University of Technology: Goteborg, Sweden, 2011.

31. Adhyaru, D.N.; Bhatt, N.S.; Modi, H.A. Enhanced production of cellulase-free, thermo-alkali-solvent-stable xylanase from Bacillus altitudinis DHN8, its characterization and application in sorghum straw saccharification. Biocat. Agric. Biotechnol. 2014, 3, 182-190. [CrossRef]

32. Nandimath, A.P.; Kharat, K.R.; Gupta, S.G.; Kharat, A.S. Optimization of cellulase production for Bacillus sp. and Pseudomonas sp. soil isolates. Afr. J. Microbiol. Res. 2016, 10, 410-419.

33. Lugani, Y.; Singla, R.; Sooch, B.S. Optimization of Cellulase Production from Newly Isolated Bacillus sp. Y3. J. Bioproc. Biotech. 2015, 5. [CrossRef]

34. Vijayakumar, R.; Muthukumar, C.; Thajuddin, N.; Panneerselvam, A.; Saravanamuthu, R. Studies on the diversity of actinomycetes in the Palk Strait region of Bay of Bengal, India. Actinomycetologica 2007, 21, 59-65. [CrossRef]

35. Insam, H.; Franke-Whittle, I.; Goberna, M. Microbes in aerobic and anaerobic waste treatment. In Microbes at Work; Springer: Berlin/Heidelberg, Germany, 2010; pp. 1-34.

36. Hamedani, K.; Soudbakhsh, M.N.; Das, A.; Prashanthi, K.; Bhattacharya, S.; Suryan, S. Enzymatic screening, antibacterial potential and molecular characterization of streptomycetes isolated from Wayanad district in Kerala, India. Int. J. Pharm. Biol. Sci. 2012, 2, 201-210.

37. Das, A.; Bhattacharya, S.; Murali, L. Production of cellulase from a thermophilic Bacillus sp. isolated from cow dung. Am.-Eurasian J. Agric. Environ. Sci. 2010, 8, 685-691.

38. Gomez, L.D.; Steele-King, C.G.; McQueen-Mason, S.J. Sustainable liquid biofuels from biomass: The writing's on the walls. New Phytol. 2008, 178, 473-485. [CrossRef] [PubMed]

39. Madson, P.W.; Tereck, C.D. Lignocellulosic. Feed Stocks for Ethanol Production: The Ultimate Renewable Energy Source. 2004. Available online: http://www.nt.ntnu.no/users/skoge/prost/proceedings/aiche2004/pdffiles/papers/035a.pdf (accessed on 10 November 2016).

40. Bayer, E.A.; Shimon, L.J.; Shoham, Y.; Lamed, R. Cellulosomes-Structure and ultrastructure. J. Struct. Biol. 1998, 124, 221-234. [CrossRef] [PubMed]

41. Iyer, P.; Singhal, R.S. Production of glutaminase (EC 3.2.1.5) from Zygosaccharomyces rouxii: Statistical optimization using response surface methodology. Bioresour. Technol. 2008, 99, 4300-4307. [CrossRef] [PubMed]

42. Iyer, P.V.; Singhal, R.S. Screening and selection of marine isolate for L-glutaminase production and media optimization using response surface methodology. Appl. Biochem. Biotechnol. 2009, 159, 233-250. [CrossRef] [PubMed]

43. Iyer, P.V.; Singhal, R.S. Glutaminase Production using Zygosaccharomyces rouxii NRRL-Y 2547: Effect of aeration, agitation regimes and feeding strategies. Chem. Eng. Technol. 2010, 33, 52-62. [CrossRef]

44. Lynd, L.R.; Weimer, P.J.; van Zyl, W.H.; Pretorius, I.S. Microbial cellulose utilization: Fundamentals and biotechnology. Microbiol. Mol. Biol. Rev. 2002, 66, 506-577. [CrossRef] [PubMed]

45. Mg, Z.L.M.; Than, W.M.; Myint, M. Study on the cellulase enzyme producing activity of bacteria isolated from manure waste and degrading soil. Int. J. Tech. Res. Appl. 2015, 3, 165-169.

46. Onsori, H.; Zamani, M.R.; Motallebi, M.; Zarghami, N. Identification of over producer strain of endo- $\beta-1$, 4-glucanase in Aspergillus species: Characterization of crude carboxymethyl cellulase. Afr. J. Biotechnol. 2005, 4, 26-30. 
47. Jansova, E.; Schwarzova, Z.; Chaloupka, J. Sporulation and synthesis of extracellular proteinases in Bacillus subtilis are more temperature-sensitive than growth. Folia Microbiol. 1993, 38, 22-24. [CrossRef]

48. Bakare, M.K.; Adewale, I.O.; Ajayi, A.; Shonukan, O.O. Purification and characterization of cellulase from the wildtype and two improved mutants of Pseudomonas fluorescens. Afr. J. Biotechnol. 2005, 4, 898-904.

49. Assareh, R.; Hossein, S.Z.; Noghabi, K.A.; Aminzadeh, S.; Khaniki, G.B. Characterization of the newly isolated Geobacillus sp. T1, the efficient cellulase-producer on untreated barley and wheat straws. Bioresour. Technol. 2012, 120, 99-105. [CrossRef] [PubMed]

50. Abdel-Fattah, Y.R.; El-Helow, E.R.; Ghanem, K.M.; Lotfy, W.A. Application of factorial designs for optimization of avicelase production by a thermophilic Geobacillus isolate. Res. J. Microbiol. 2007, 2, $13-23$.

51. Monisha, R.; Uma, M.V.; Murthy, V.K. Partial purification and characterization of Bacillus pumilus xylanase from soil source. Kathmandu Univ. J. Sci. Eng. Technol. 2009, 5, 137-148.

52. Sepahy, A.A.; Ghazi, S.; Sepahy, M.A. Cost-Effective production and optimization of alkaline xylanase by indigenous Bacillus mojavensis AG137 fermented on agricultural waste. Enzyme Res. 2011. [CrossRef]

53. Simphiwe, P.; Ademola, B.; Olaniran, O.; Pillay, B. Sawdust and digestive bran as cheap alternate substrates for xylanase production. Afr. J. Microbiol. Res. 2011, 5, 742-752. [CrossRef]

54. Okaiyeto, K.; Nwodo, U.U.; Okoli, S.A.; Mabinya, L.V.; Okoh, A.I. Implications for public health demands alternatives to inorganic and synthetic flocculants: Bioflocculants as important candidates. Microbiol. Open 2016, 5, 177-211. [CrossRef] [PubMed]

55. Fatokun, E.N.; Nwodo, U.U.; Okoh, A.I. Classical optimization of cellulase and xylanase production by a marine Streptomyces species. Appl. Sci. 2016, 6. [CrossRef]

56. Liang, Y.; Feng, Z.; Yesuf, J.; Blackburn, J.W. Optimization of growth medium and enzyme assay conditions for crude cellulases produced by a novel thermophilic and cellulolytic bacterium, Anoxybacillus sp. Appl. Biochem. Biotechnol. 2009. [CrossRef] [PubMed]

57. Nasr, S.A.; Abozaid, A.A.; Hussein, N.A.; Al-Salemi, F.A. Cellulase production by local bacteria isolated from Taif in Saudi Arabia. J. Agric. Sci. 2011, 19, 163-170.

58. Padilha, I.Q.M.; Carvalho, L.C.T.; Dias, P.V.S.; Grisi, T.C.S.L.; da Silva, F.L.H.; Santo, S.F.M.; Araujo, D.A.M. Production and characterization of thermophilic carboxymethylcellulase synthesized by Bacillus sp. growing on sugarcane bagasse in submerged fermentation. Braz. J. Chem. Eng. 2015, 32, 35-42. [CrossRef]

59. Gessesse, A. Purification and properties of two thermostable alkaline xylanases from an alkaliphilic Bacillus sp. Appl. Environ. Microbiol. 1998, 64, 3533-3535. [PubMed]

60. Rani, D.S.; Nand, K. Production of thermostable cellulase-free xylanase by Clostridium absonum CFR-702. Proc. Biochem. 2000, 36, 355-362. [CrossRef]

61. Pereira, M.A.; Jacobs, D.R., Jr.; Van Horn, L.; Slattery, M.L.; Kartashov, A.I.; Ludwig, D.S. Dairy consumption, obesity, and the insulin resistance syndrome in young adults: The CARDIA Study. JAMA 2002, 287, 2081-2089. [CrossRef] [PubMed]

62. Park, D.; Zeikus, J. Impact of electrode composition on electricity generation in a single-compartment fuel cell using Shewanella putrefaciens. Appl. Microbiol. Biotechnol. 2002, 59, 58-61. [PubMed]

63. Bano, S.; Qader, S.A.U.; Aman, A.; Syed, M.N.; Durrani, K. High production of cellulose degrading endo-1, 4- $\beta$-D-glucanase using bagasse as a substrate from Bacillus subtilis KIBGE HAS. Carbohydr. Polym. 2013, 91 , 300-304. [CrossRef] [PubMed]

64. Giavasis, I.; Harvey, L.M.; McNeil, B. The effect of agitation and aeration on the synthesis and molecular weight of gellan in batch cultures of Sphingomonas paucimobilis. Enzyme Microb. Technol. 2006, 38, 101-108. [CrossRef]

65. El-Refai, H.A.; AbdElRahman, H.Y.; Abdulla, H.; Hanna, A.G.; Hashem, A.H.; El-Refai, A.H.; Ahmed, E.M. Studies on the production of actinomycin by Nocardioides luteus, a novel source. Curr. Trends Biotechnol. Pharm. 2011, 5, 1282-1297.

66. Kokare, C.R.; Kadam, S.S.; Mahadik, K.R.; Chopade, B.A. Studies on bioemulsifier production from marine Streptomyces sp. S1. Indian J. Biotechnol. 2007, 6, 78-84.

67. Nagendra, H.; Southworth, J.; Tucker, C. Accessibility as a determinant of landscape transformation in western Honduras: Linking pattern and process. Landsc. Ecol. 2003, 18, 141-158. [CrossRef]

68. Ariffin, H.; Abdullah, N.; Umi Kalsom, M.S.; Shirai, Y.; Hassan, M.A. Production and characterisation of cellulase by Bacillus pumilus EB3. Int. J. Eng. Technol. 2006, 3, 47-53. 
69. Sharma, A.; Adhikari, S.; Satyanarayana, T. Alkali-Thermostable and cellulase-free xylanase production by an extreme thermophile Geobacillus thermoleovorans. World J. Microbiol. Biotechnol. 2007, 23, 483-490. [CrossRef]

70. Mrudula, S.; Shyam, N. Immobilization of Bacillus megaterium MTCC 2444 by Ca-alginate entrapment method for enhanced alkaline protease production. Braz. Arch. Biol. Technol. 2012, 55, 135-144. [CrossRef]

71. Gupta, U.; Kar, R. Xylanase production by a thermo-tolerant Bacillus species under solid-state and submerged fermentation. Braz. Arch. Biol. Technol. 2009, 52, 1363-1371. [CrossRef]

72. Murugan, S.; Arnold, D.; Pongiya, U.D.; Narayanan, P.M. Production of xylanase from Arthrobacter sp. MTCC 6915 using saw dust as substrate under solid state fermentation. Enzyme Res. 2011, 7, 696942.

(C) 2016 by the authors; licensee MDPI, Basel, Switzerland. This article is an open access article distributed under the terms and conditions of the Creative Commons Attribution (CC-BY) license (http://creativecommons.org/licenses/by/4.0/). 